\title{
Aesthetic Component in the Formation of Lexical Area "Art" in English Language Classes
}

\author{
Olga A. Kiyashchenko ${ }^{1}$, Ekaterina A. Plakhova ${ }^{1} \&$ Makhfuza A. Rakhimova ${ }^{1}$ \\ ${ }^{1}$ Kazan (Volga Region) Federal University, Kazan, Russia \\ Correspondence: Olga A. Kiyashchenko, Kazan (Volga Region) Federal University, 420008, Kazan, \\ Kremlyovskaya Street 18, Russia. E-mail: kiyashenko@mail.ru
}

Received: June 2, 2015 Accepted: June 15, 2015 Online Published: June 29, 2015

doi:10.5539/jsd.v8n5p191 URL: http://dx.doi.org/10.5539/jsd.v8n5p191

\begin{abstract}
The relevance of the research problem is determined by the necessity to enhance cognitive and educational functions due to humanization of education by means of art. The purpose of the article is to identify, analyze and define the ways of forming a lexical area "art" in the process of teaching students English through the realization of the aesthetic component. A leading approach to the study of this problem is a theoretical and an empirical one. The article presents the results, indicating the importance of the use of paintings, illustrations, fiction, elements of folklore (proverbs, sayings) in English classes; the sources of the vocabulary formation in the sphere of art have been identified and analyzed with the view of parallel implementation of the component of aesthetic education. The article can be useful in studies related to the process of English language teaching and implementation of the educational function in the field of aesthetics education.
\end{abstract}

Keywords: art, painting, theatre, vocabulary, literature, students, teaching, aesthetic education

\section{Introduction}

Before setting out to explore the theme "art" and the formation of appropriate vocabulary, we consider it necessary to define its place in the system of aesthetic education.

The process of aesthetic education is diverse and takes the leading position in the system of the world outlook formation of an individual. The word aesthetics is of Greek origin, which means "pertaining to sensitive perception". It was first used by the German philosopher Alexander Baumgarten (Philosophical reflections, 1735) to denote a new section of philosophy This word stuck in philosophical terminology, and since the middle of the XYIIIth century aesthetics came to be understood as the scientific study of either "philosophy of beauty" or "philosophy of art". Aesthetics considers sensitive perception of reality and deals with its different aspects: nature, society, man and his activities. One of the key issues within the terms of the study of aesthetics is art,( Kurenkova, 2004). Functions of art are diverse: aesthetic (allows to take reality according to the laws of beauty, forms aesthetic taste); social (has an ideological impact on society, thereby transforming the social reality); educational (manifests itself in the ability of art to shape one's own personality); hedonistic (reflects the capacity of art to bring a man pleasure, joy); prognostic (indicates the ability of art to make forecasts and predict the future (L. da Vinci, G.Wells, I. Efremov, R. Bradberry).

One cannot but agree with the fact that Vita brevis, ars longa. But what exactly is "art"? On the one hand, it is understood as the highest degree of skill, abilities, when one talks about the art of the surgeon, teacher, potter, tailor, as a specialist of the highest level. The second meaning of this word is "a special subsystem of the spiritual aspects of life, society, representing an artistic reproduction of reality in artistic images" (Ozhegov, 1970).

Undoubtedly, art is an artistic creation in general, which covers such areas as literature, architecture, painting, music, theatre, cinema, united by artistic and imaginative forms of reflection of reality.

It is not uninteresting for a person to learn how his personal perception of art resonates with the perception of bygone great people who lived and created art. That is why we refer to them, we cite them and discuss in class: "Painting argues and competes with nature", "Where the spirit does not drive the hand of an artist, there is no art." "Painting is poetry which is seen, and poetry is painting which is heard" (Leonardo da Vinci). "Artist thinks with drawing" (Salvator Dali), "The task of art is to excite hearts" ( Helvetius), "The value of art lies not in beauty but in moral behavior" ( S. Maugham), "Art is mystery ( E. Grieg), "At the moment the artist thinks about money, he 
loses the sense of beauty" (D. Diderot), "We use colours, but paint with feelings" (J. Chardin), "Art is the expression of the deepest thoughts in the simplest way" (A.Einstein), "Great art has two deviations from the path banality and artificiality" (L. N. Tolstoy), "Music makes concessions to love only" (Pushkin, 1959).

With these remarks, we can agree or disagry, but nobody can remain indifferent to art.

Teaching in English class is mainly based on the aesthetic and educational function of art.

The educational possibilities of the subject consists in the content of educational materials used in personality and behavior of the teacher (Solov'yova, 2005). Teaching English one should remember that aims are the first and the most important consideration in any teaching (Rogova, 1975). So, we use practical, educational and cultural aims in English language teaching.

Language is a means of communication. Vocabulary is the main force in the system of language means engaged in meaningful semantic relationships. The main objective of the lexical aspect of language learning is to master the usage of words, which requires not only knowledge of words, but also the ability to manipulate them in speech.. Lexical skill reflects the relationship between the classes of words and summarizes the information. Moreover, vocabulary individualizes statement, gives it a specific meaning. The formation of lexical area of a particular topic and the formation of lexical skills should be continuously kept in sight of the teacher. Without solid knowledge and skills in the area of vocabulary the successful development of reading, writing, speaking and listening is impossible. Work on the new vocabulary is done in stages:

1st stage - introduction;

2nd stage - initial retention;

3rd stage - the development of skills and abilities to use vocabulary in different forms of oral and written communication.

New words should be exercised both in isolation and in context, because the contextual meaning of the word is the key point when reading the text (Konysheva, 2011).

Introducing a new word, one must use word combinations also. Proceeding the theme "art" English teacher should set the problems to be solved:

- to increase topical vocabulary, to develop the skills of making use of the new words and expressions;

- to teach students to manage the gained knowledge in micro situations, dialogues, discussions;

- to develop self-educational ability and creativity of the students. (Voronikhina, 1978).

We start teaching topic "art" with the introduction of the new words choosing one of the methods available ( in dependence with the type of the lesson, its goals and objectives:

1) a story with the elements of conversation; (Leont'ev, 2007).

2) presentation of the new words in conversation;

3) presentation of the new words in sentences;

4) presentation of the new words in certain situations;

5) presentation of a separate list of words.

Semantization of topical vocabulary can be done in different ways, words are united into two groups due to:

a) translation approach

b) direct (without translation) approach.

Translation approach includes: (Gal'skova, 2009).

1) replacement of a word, phrase or expression with a corresponding equivalent in native language;

2) translation of a word - interpretation in which in addition to the equivalent in student's native language there is information about the compliance or discrepancy in number of meanings: big - large in size, great - famous .

Direct (without translation) approach includes:

1) demonstration of objects, gestures, actions, paintings, drawings, and so on;

2) disclosure of the meanings of the words proceeded in a foreign language (English), which may use -

a) definition, that is description of a meaning of the word - it reveals a meaning, a conceptual nature of a word;

b) enumeration: dogs, cats, cows - are animals 
c) semantization through synonyms and antonyms: cold - warm, quick - slow;

d) definition of the word based on its internal form: framework ( known ) + derivational elements: work + er

e) compound word consisting of two elements: timetable

f) words similar in spelling and sound in their native language: club, park, photograph, patriot;

g) definition of the word based on context inference, knowledge of the facts: Columbus discovered America.

Translation is economical in terms of time, is universal in use, but increases possibility of inter-language interference.(Babinskaya, 2006).

Teaching the topic «English painting» in English classes reproductions of such English artists as W.Hogarth, T.Gainsborough, Reynolds, Constable, Turner, Romney, Lawrence are widely used (Verman, 2000).

Direct method develops a guess, increases practice in language, creates support for remembering, strengthens the associative links, but it requires more time than translation method and does not always ensure accurate understanding.

At the first stage, after introduction of the new words different types of lexical exercises are made.

Assimilation is gained through performing various exercises. To attain the desired end pupils must first of all perform various exercises to fix the words in their memory. Constant use of a new word is the best way of learning it (Boyko, 2006).

Then, based on the learnt before "art" topical vocabulary students describe household items, clothing, appearance and character of the people depicted in paintings, as well as genre, style and artist's own manner of painting .(Dmitrieva, 1996).

Juging from the external signs (appearance, clothing, surrounding subjects) students try to identify the epoch and characters of people depicted in pictures. (Fal'kovich, 1976)

Another type of assignment is to comment on and discuss in groups of 2 or 3 people famous sayings or proverbs, such as: (Rum'antseva, 2008)

1) Art is long and life is fleeting .

2) A picture is a poem without words..

3) All art is but imitation of nature..

At the third stage of work with the learnt topical vocabulary "art" students prepare their own presentations of artists' painting of different countries, centuries and genres and describe pictures they have chosen during their joint visit with the teacher to art galleries.

While intensifying "art" vocabulary we use different types of speech activity - monologue, dialogue, presentation, discussion.Oxenden Clive, 2013)

It should be noted that literary text is also one of the most effective means of forming lexical skill, as it is in the literary text that one can find lexical units of various styles and areas of application. In the text you can deal with literary words, and with slang because language of a literary text is rich and diverse (Babenko, 2004)..The task of the artistic style used in literary works, is to paint a picture by means of words, to express its attitude, to influence the perception and imagination of a reader. And of course they must be highly artistic samples of prose and poetry.

Forming lexical zone "art" in English classes, we use to read and analyze the following works of art, the content of which is relevant to art:

The Last Leaf (Henry, 2011)

Art for heart's sake (Goldberg, 2003)

Theatre (Maugham, 2004)

The Moon and sixpence (S. Maugham, 2007)

The picture of Dorian Gray ( Wild, 2014).

\section{Methodological Framework}

Formation of aesthetic views, tastes and ideals of the students is carried out by various methods. Methods of Aesthetic Education is a system of methods of educational activities with the aim of aesthetic development. Traditionally, there are three kinds of methods: verbal, visual and practical. 
Verbal methods include a story, a conversation, an explanation and discussion, allowing not only to present the material, but also to control its understanding, to raise the problem, etc .Visual methods include demonstration of illustrations, films, diagrams.

Practical methods embrace testing, control and original works, which allow a teacher to determine the level of mastering the topic and with the view of it plan further lessons, improving them.

It is necessary to reveal the differences of concepts such as "method of artistic perception of reality" and "method of aesthetic perception". Method of artistic perception of reality is realized through art, because it is concentrated in the most pure form of the aesthetic attitude of a man to reality and through the cognition of the essence of aesthetic categories and laws.

Method of aesthetic perception and attitude towards nature is realized by means of perception of objects and phenomena of the external world. Aesthetic education of love for nature, everything that surrounds human life and its perception presupposes knowledge of nature itself, and this knowledge is acquired by direct experiences and practice, as well as by theoretical knowledge, given by education. Forming lexical area "art", we resort to the use of both methods.

\section{Results}

As a result of the study: sources of formation of lexical zone "art" in such sections as "painting", "literature", "folklore" have been determined; "art" vocabulary has been increased and the skills to use these words and expressions have been developed; "art" vocabulary has been selected and lexical minimum has been formed so that to provide students ability to speak out on this topic in monologues and dialogues, and to take active part in discussions; students' ability and skill to adequately use proverbs, sayings, quotes in English speech has been developed; lexical exercises designed to form vocabulary have been selected and compiled; ways of introducing new vocabulary have been found; stages of work upon "art" vocabulary have been defined; self-educational methods and techniques of potential creative activity of students have been defined.

"Painting" topical vocabulary has been formed in the following aspects:

1. painters and their craft (a fashionable/self-taught/mature artist, a portrait/landscape painter, to paint from nature/memory/imagination, to paint mythological/historical subjects, to specialize in portraiture/still life, to portray people/emotions with moving sincerity / with restraint, to depict a person/a scene of common life, to reveal the person's nature, to capture the sitter's vitality/transient expression, to develop one's style of painting, to break with the traditions, to be in advance of one's time, to become famous overnight, to die forgotten and penniless) (Arakin, 2003)

2. paintings, genres, (Verman Karl, 1944),

3. composition and drawing,

4. colouring, light and shade effects,

5. impression, judgment. (Istoria zhivopisy A.N. Benua (2009), from http://www.benua-histori.ru/main.html)

\section{Discussions}

Aristotle wrote a work entitled "On the art of poetry" (1975), Hegel - "Aesthetics" (lectures) (1958), Kant "Critique of Judgment"(1963-1966).. Many well-known teachers such as Pestalocci (1981), Gumbol'dt (1985), Tolstoy ( 1978-1985), Ushinsky (1988-1990) recognized the huge role of moral and aesthetic education in shaping personality.

Some modern Russian scientists in the sphere of education, such as Passov (1975), Rogova (1975), Leont'ev, (2007) . did not disregard the educational aspect of the subject "foreign language".

Over the centuries there were two points of view on the relation of beauty and reality. The first point of view, which in was adhered in Russia by Chernyshevsky (1947), is that the beautiful in life is always and in all respects above the beautiful in art, that is, art is a copy of the typical characters and objects of reality itself, its substitute. Chernyshevsky denied art, remote from real life, gravitating to the ghostly images of fruitless fantasy.

Hegel (1958), Gertsen (1919 1925), and others adhered to the second point of view - the beautiful in art is above the beautiful in life, as an artist sees deeper and more accurate, feels stronger and brighter and that is why he may inspire others with his art.

This issue is put forward for discussion by the students in English classes. Discussing, they seek to substantiate their devotion to the first or the second point of view, using in speech already learned and assimilated, fairly extensive "art" vocabulary (Cotton David, 2013). 


\section{Conclusion}

The relevance of getting down to the issues of spirituality is due to the presence of signs of dynamic transformation of axiosphere (values) of our society, the formation of some vacuum which is quickly filled by "mass culture".

As far as the process of formation of "art" lexical area in English classes is concerned it should be noted that:

- differentiated approach to the selection of vocabulary, presentation and retention aimed at enhancing the level of effective vocabulary teaching is required: lexical knowledge ensures successful mastering of the basics of all kinds of speech activity;

- reading of literary texts, followed by discussion is a means of teaching, the source of enlargement of vocabulary;

- reading of fiction develops the students' skills of independent work with the vocabulary;

- usage of illustrations in teaching "painting" topic is a prerequisite for successful mastering of the vocabulary, motivating communicative activities of students in class;

- work with "art" vocabulary helps to expand the artistic horizons of students, instilling an interest in art, develops aesthetic taste;

- lexical assimilation in the sphere of "art", "painting", "literature" can be carried out in accordance with the principle of lexical advance.

\section{Recommendations}

Materials of the article may be of interest to those involved in the process of education and training through English language.

\section{Acknowledgments}

This work was funded by the subsidy allocated to Kazan Federal University for the state assignment in the sphere of scientific activities.

\section{References}

Arakin, V. D. (2003). Prakticheskiy kurs angliyskogo yazyka (3 kurs). Uchebnik dlya vuzov. Moskva: VLADOS.

Aristotel. (1975). Sochinenija. Moskva Mysl.

Babenko, L. G. (2004). Filologicheskiy analiz teksta. Osnovy teorii, printsipy i aspekty analiza. Ekaterinburg.

Babinskaya, P. K., \& Leont'eva, T. P. (2006). Prakticheskiy kurs metodiki prepodavaniya IY. Minsk.

Boyko, V. A., \& Postnov, O. G. (2006). Kritika i semiotika. Vyp Novosibirsk-Moskva.

Chernyshevskij, N. G. (1947). Polnoe sobranie sochinenij. Moskva. Goslitizdat.

Clive, O., \& Christina, L.-K. (2013). New English File. Advanced Student's Book. Oxford University Press.

David, C., David, F., Simon, K., Jan, L., \& Gareth, R. (2013). Language Leader. Advanced Course book. Longman.

Dmitrieva, N. A. (1996). Iskusstvo Anglii XVIII veka, Kratkaya istoriya iskusstv,kniga vtoraya. Moskva.

Fal'kovich, M. M., Lebedinskaya, E. M., Strelkova, N. S., \& Tsigel'naya, A. D. (1976). How to speak about art in English. Moskva. Mezhdunarodniye otnosheniya.

Gal'skova, N. D., \& Gez, N. I. (2009). Obucheniya inostrannym yazykam. Lingvodidaktika i metodika. Moskva. Akademiya.

Gertsen, A. I. (1919-1925). Polnoe sobranie sochinenij i pisem pod redaktsiej M.K.Lemke (t.t.I-XXII).

Gumbol'dt Vil'gel'm. (1985). JAZYK I FILOSOFIJA KUL"TURY MOSKVA PROGRESS.

Hegel, G. (1958). Lektsii po estetike. Kniga tret'ya. (Sochineniya, tom XIV). Moskva.

Henry, O. (2011). The Last Leaf. Kniga po trebovaniyu.

Istoria zhivopisy A.N. Benua. (2009). Retrieved from http://www.benua-histori.ru/main.html

Kant.Immanuil. (1963-1966). Sochinenija v shesti tomah. Moskva.

Karl, V. (1944). Istoriya iskusstva vsekh vremen $i$ narodov (v 3-kh tomakh). Retrieve from http://www.verman-art.ru/

Karl, V. (2000). Istoriya iskusstva vsekh vremen i narodov (v 3-kh tomakh). Sankt-Peterburg: Poligon. 
Kodzhaspirova, G. M. (2004). Pedagogika. Moskva: VLADOS.

Konysheva, A. V. (2011). Sovremennye metody obucheniya angliyskomu yazyku. Minsk. TetraSistems.

Kurenkova, R. A. (2004). Estetika. Moskva: VLADOS-PRESS.

Leont'ev, A. A. (2007). Yazyk, rech', rechevaya deyatel'nost. Moskva: Prosvyashchenie.

Maugham, W. S. (2004). Theatre. Moskva. Menedjment.

Maugham, W. S. (2007). The Moon and sixpence. Kniga po trebovaniyu.

Ozhegov, S. I. (1970). Slovar' russkogo yazika. Moskva. Sovetskaya Entsiklopediya.

Pestalotstsi, I. G. (1981). Izbr. ped. soch.: V 2 t. Moskva.

Pushkin, A. S. (1959). Kamenniy Gost'.PSS, t.7. Moskva. Akademiya Nauk SSSR.

Rogova, G. V. (1975). Methods of teaching English. Leningrad: Prosvyashchenie.

Rum'antseva, I. M. (2008). Russkye i angliyskiye poslovitsi i pogovorki. Moskva, Filomatis.

Solov'yova, E. N. (2005). Metodika obucheniya inostrannym yazykam. Bazovyy kurs lektsiy. Posobie dlya studentov pedagogicheskikh vuzov i uchiteley. 3-e izd. Moskva: Prosveshchenie.

Tolstoj, L. N. (1978-1985). Sobranie sochinenij v 22 tomakh. Moskva.: «KHudozhestvennaya literatura».

Ushinsky, K. D. (1988). Pedagogical works in 6 T. - T. 2. Moskva.

Voronikhina, L. N., \& Mikhailova, T. M. (1978). Glimpses of British Art. Leningrad. Prosveshchenie.

Wilde, O. (2014). The picture of Dorian Gray. AST.

\section{Copyrights}

Copyright for this article is retained by the author(s), with first publication rights granted to the journal.

This is an open-access article distributed under the terms and conditions of the Creative Commons Attribution license (http://creativecommons.org/licenses/by/3.0/). 